DOI: https://doi.org/10.31538/ndh.v5i3.1002

http://e-journal.ikhac.ac.id/index.php/nidhomulhaq

\title{
THE ROLE OF STAKEHOLDER IN BUILDING A BRAND IMAGE AT MADRASAH ALIYAH
}

\author{
Fajri Dwiyama1), Nurhasanah $\mathbf{R}^{2)}$ \\ ${ }^{1}$ Institut Agama Islam Negeri (IAIN) Bone, Indonesia \\ email: fajridwiyama@gmail.com \\ 2 Sekolah Tinggi Agama Islam (STAI) Al-Gazali Bone, Indonesia \\ email: zhananurhasanah@gmail.com
}

\begin{abstract}
Brand image is a representation of the overall perception of a brand and is formed from information and knowledge of that brand. Having a positive brand image for educational institutions in today's global competition is very important. The existence of a brand image is an alternative in winning the education marketing competition. A positive brand image is formed from the continuous role of various elements of stakeholders in educational institutions. Madrasah Aliyah Al-Ikhlas Ujung Bone is one of the private educational institutions established in the pesantren environment, which has a very good brand image. The indicator appears from the high public interest in these educational institutions. Even though they have a brand image, there is no visible role of school residents in building this brand image. This is the reason behind this research. The type of research used is qualitative research, data collection methods in the form of observation, interviews and documentation. Data analysis techniques are data reduction, data display, and drawing conclusions. The results of the study were related to the role of school members in building image bran, namely: 1) the characteristics of the brand image in Madrasah Aliyah Al-Ikhlas Ujung Bone, namely the existence of a strong image of the maker, the image of the user and the image of production. 2) the role of school members in building brand image, namely forming perceptions, maintaining perceptions, and changing perceptions.
\end{abstract}

Keywords: Stakeholder Madrasah, Brand Image Institution, Perception of Stakeholder.

\begin{abstract}
Abstrak
Brand image merupakan representasi dari keseluruban persepsi terhadap merek dan dibentuk dari informasi dan pengetabuan terbadap merek itu. Memiliki sebuah brand image yang positif bagi lembaga pendidikan dalam persaingan global saat ini sangatlah penting. Keberadaan brand image menjadi suatu alternatif dalam memenangkan persaingan pemasaran pendidikan. Brand image positif terbentuk dari peran berbagai unsur pemangku kepentingan pada lembaga pendidikan secara terus-menerus. Madrasah Aliyah Al-Ikblas Ujung Bone merupakan salah satu lembaga pendidikan berstatus swasta berdiri dilingkungan pesantren, yang memiliki brand image sangat baik. Indikator nampak dari tingginya minat masyarakat terbadap lembaga pendidikan tersebut. Meski memilki brand image namun belum nampak peran warga sekolah dalam membangun brand image tersebut. Inilah yang melatarbelakangi dilakukannya penelitian ini. Adapun Jenis penelitian yang digunakan yakni penelitian kualitatif, metode pengumpulan data berupa observasi, wawancara dan dokumentasi. Teknik. Analisis data yaitu reduksi data, display data, dan penarikan kesimpulan. Hasil penelitian menganai peran warga sekolah dalam membangun bran image yaitu: 1) karakteristik brand image di Madrsah Aliyah Al-Ikblas Ujung Bone yaitu adanya citra pembuat, citra pemakai dan citra produksi yang kuat. 2) peran warga sekolah dalam membangun brand image yaitu membentuk, persepsi, memelihara persepsi, dan mengubah persepsi.
\end{abstract}

Kata Kunci: Warga Madrasah/Sekolah, Citra Merek Lembaga, Persepsi Warga Madrasah.

\section{INTODUCTION}

The government's efforts to continue to develop the quality of education in Indonesia continue to be intensified
(Akhyadi \& Mulyono, 2019; R \& Ummah, 2019; Suwadi, 2017). One of the major steps in improving education is the provision of broad educational autonomy for schools, by 
implementing school-based management (Sharma et al., 2013; Suwadi, 2017). Schoolbased management should provide flexibility to educational institutions to manage and regulate many things related to school policy independently (Ismail, 2018). Empowerment of schools through the provision of greater autonomy is intended so that schools are able to independently improve the quality of education, carry out efficiency in institutional management, and create equitable education in this country (Asyari et al., 2018; Muhammadi et al., 2015).

The management of educational institutions which are now autonomous has become quite interesting. Educational institutions are not only required to improve the quality of institutional management, but also be able to market their own educational products (DWIYAMA, 2019). Even though the implementation of education looks uniform, on the one hand there have been quite basic changes in educational institutions, especially in attracting new student candidates, and the public in participating and collaborating on the educational activities carried out. There is no doubt that educational autonomy, consciously or unconsciously, has opened the door to competition between educational institutions of an equal degree (Chen \& Chen, 2014; Plumeyer et al., 2019).
The public looks more at an educational institution as a corporate that provides educational services (Alfiyanto, 2020). If you want to enjoy an education services, consumers must participate in activities p Education, considering product services can not be seen and felt before consuming it directly. Consumers also cannot know the quality of an educational service product before consuming it by buying it directly(Plungpongpan et al., 2016). If an educational institution is unable to market educational services, because consumers feel less confident about the services offered, the production of the services marketed will not be bought (S. Alwi et al., 2019; S. F. S. Alwi \& Kitchen, 2014).

This has an impact on the existence of educational institutions in the community, where the life of the institution depends on the participation of the participating community (Ahmad, 2015). Facing educational competition, especially in service marketing, a strategy is needed to win the competition. Having a positive brand image for educational institutions in today's global competition is very important. The existence of a brand image is an alternative in winning the education marketing competition (Schwab, 2016). 
Hermawan (Kartajaya, 2006), one of the marketing experts, revealed that all steps taken towards the product are actually part of the effort to build a brand. A brand is not just a name, not just a logo or symbol, but a brand is an umbrella that represents a product or service of a product or service. Brand is a reflection of the value provided to customers. This reflection of value then attracts customers to consume a service offered, in this case educational services(Plumeyer et al., 2019).

From the above statement, it can be concluded that brand image greatly influences people's views on the good and bad of an educational institution, which then influences them to participate in that educational institution. Facts in the field, especially in Bone Regency, show that there are still many educational institutions that have less awareness to build a positive brand image so that most educational institutions are not ready to face educational marketing competition.

The election of Madarasah Aliyah (MA) Al-Ikhlas Ujung Bone is based on the fact that this institution is one of the private educational institutions in the pesantren environment, which has a very good brand image. The indicator can be seen from the high public interest in these educational institutions . Based o bservasi early conducted research on the role of the school community in building the brand image is fairly unremarkable, routine school community as well as other educational institutions. This is what attracts the author's interest to conduct further research on the efforts made by school residents in building a positive brand image, especially at MA Al-Ikhlas Ujung Bone. The purpose of this study was to determine: 1) the characteristics of the brand image at MA AlIkhlas Ujung Bone, 2) The role of the school community in building a brand image at Madarasah Aliyah (MA) Al-Ikhlas Ujung Bone.

\section{LITERATURE REVIEW}

The discussion presented in this study is an explanation that describes the role of school members in building a brand image at MA Al-Ikhlas Ujung Bone. The subject matter to be studied is related to the results of research that have been carried out by several previous researchers, therefore the researcher reveals several research results that are considered to have a relationship with this research, both research results in the form of a thesis, and research results in the form of other scientific papers.

Research conducted by Yulia Rukmana in 2016 with the research title "Strategy to Build a Brand Image in Increasing the Competitiveness of Educational Institutions (Multi Case Study in SMAN 3 Malang and SMA Nurul Jadid Paiton Probolinggo). The research 
objective was to determine the factors of brand image formation, the steps for school strategies to build a brand image in increasing competitiveness, and the impact of forming a brand image in increasing competitiveness. The results of his research show that: 1) the factors forming the school's brand image include institutional accreditation, ISO, student behavior, achievement, quality of graduates, school excellence activities, and alumni relations. 2) L steps for school strategies to build brand image in enhancing the competitiveness of the school include institutional accreditation, ISO, make $\mathrm{k}$ egiatan featured for, strengthening ties of alumni . 3) The impact of forming a brand image in increasing the competitiveness of schools, namely: the quality of service for teachers and employees is better, interest in entering the community increases, students have good character, high public trust, offers of scholarships abroad, and many educational institutions conduct studies appeal (RUKMANA, 2016).

The relevance of the research that will be carried out on the research that has been done by Yulia Rukmana's sister lies in the problem of brand image as the object of research. While the difference is that Yulia Rukmana focuses her research on increasing the competitiveness of institutions by building a brand image, while the research that will be carried out by the author focuses on the role of school members in building brand image. In addition, different research locations allow different research results to be obtained.

Furthermore, the research conducted by Ahmad Elly Wibowo in 2018 with the title " Strategies to Build a Brand Image in Increasing the Competitiveness of Educational Institutions $M A N 2$ Ponorogo". The research aims to analyze the strategy of building brand image in increasing the competitiveness of educational institutions of MAN 2 Ponorogo, analyzing the factors forming brand image in increasing the competitiveness of educational institutions in MAN 2 Ponorogo, knowing the implications of building a brand image image in increasing the competitiveness of educational institutions MAN 2 Ponorogo . The research results are: 1) MAN 2 Ponorogo builds a brand image in increasing the competitiveness of the institution through three strategies, namely positioning, differenting, and branding. 2) the factors of building brand image in increasing the competitiveness of MAN 2 Ponorogo institutions are: institutional accreditation, student behavior, achievement, quality of graduates, excellent school activities, and alumni relations. 3) The implications of forming a brand image in increasing school competitiveness, namely: a) the quality of 
service for teachers and employees is better, b) interest in entering the community towards schools increases, c) students have good character, d) high community trust in schools (Wibowo, 2018)

Furthermore, the research results of Zainur Roziqin and Hefny Rozaq in 2018 with the title "Initiating Competitive Advantage Through Branding Image at Madrasah Aliyah Nurul Jadid Paiton Probolinggo". The conclusion of the research results is that building a branding image of an institution is very important to provide a positive perception of the community and users of educational services towards certain institutions. Of course, in building a positive branding image of an institution, there are several factors that support the formation process. Such as some of the factors used by Madrasah Aliyah Nurul Jadid in building branding image in the institution's competitive advantage are to prioritize 1) Institutional Accreditation, 2) Professionalism of Educators, 3) Student Behavior, 4) Excellent Madrasah Activities, 5) Student Achievements, 6) Quality of Graduates, 7) Alumni Relations and excellent activities that are integrated and supported by the Pesantren. That way the management hopes that with these several factors the institution can get the best label by the community and provide good service and can compete optimally with other institutions while remaining based on the National Education Standards (Roziqin \& Rozaq, 2018)

Research conducted by Zainur Rozikin and Hefny Rozak about brand image in Mandrasah Aliyah Jadid Paiton Probolinggo has a strong relevance to the research that will be conducted by the author. The relevance lies in the similarity of one of the research variables, namely the brending image, where Zainur and Hefny have described the importance of building a brending image in educational institutions, which is also the author's goal to further investigate this matter. The difference is that it lies in the focus of their research where Zainur and Hefny focus on how the brend image improves school competence, while the research that the author will do focuses on how the role of school residents in building the brand image.

\section{Brand Image}

The term brand comes from the word brandr which means " to brand ", which is an activity that is often carried out by cattle breeders in America by marking their livestock to facilitate identification of ownership before being sold to the market (Andi, 2009). Brand is an indicator of value offered to customers, brand is an asset that creates value for customers by strengthening their satisfaction and 
loyalty, brand is a measuring tool for the quality of value offered.

Kotler stated that "a brand is a name, term, sign, symbol, or design or a combination of them, intended to identity the goods or servicesof one seller or group of seller and to differentiate them from those competitors" (P. Kotler \& Keller, 2009). Brand is a name, term, sign, symbol, or design or a combination of both, which is intended to identify the goods or services of one seller or group of sellers and to distinguish them from competitors.

Meanwhile, Leslie De Chernatony and Mc Donald argue that "brand is an identifiable product, service, person or place, augmented in such a way that the buyer or user perceives relevant, unique, sustainable added values which match their needs mostclosely" (de Chernatony \& McDonald, 2012). A brand is an identifiable identity of a product, service, person or place, augmented in such a way that buyers or users perceive the added value that is relevant, unique and sustainable that best fits their needs.

From some of the opinions above, it can be concluded that a brand is a symbol used as a marker or a distinguishing identity owned by an institution as a form of the existence of an institution. Brands in educational institutions are usually manifested by the symbol and name of the educational organization which aims as an identification.

The image is formed from how the institution carries out operational activities which have a main foundation in terms of services. Image is also formed based on impressions and based on someone's experience of something, thus building a mental attitude. Kotler stated that a positive consumer image of a brand allows consumers to make purchases. A good brand is also the basis for building a positive institutional image. According to Kotler and Keller, image (image) is the belief, idea and impression that a person holds on an object (Philip Kotler \& Keller, 2009). Most of the attitudes and actions of people towards an object are influenced by the image of an object. According to Buchari Alma, image is an impression, impression, feeling or perception that exists in the public about a company, object, person or institution (Philip Kotler, 2011)

Meanwhile, according to Levitt said that "image is the impression, feeling, the conception which the public has of a company or organization, a conditionally created of an object, person or organization" (Ibrahim \& Hamidah, 2017) Meaning: image is an appreciation, a feeling that exists in the public about a company or institution, regarding an object, person or institution. This image cannot be printed 
like printing goods at a factory, but this image is an impression that is obtained according to one's knowledge, understanding of something.

From the explanation above related to brand and image, it can be concluded that if the brand is a symbol, the image is a bright image of that symbol. Based on these two things, the brand image is a representation of the overall perception of a brand and is formed from information and knowledge of the brand. According to Kotller and Keller, brand image is a perception of a brand as reflected by brand associations in the minds of consumers (Kotler, 2013).

The components that make up a brand image according to Simamora are as follows:

:Maker image is a set of associations that consumers perceive the company that makes a product or service. corporate image has a significant influence on purchasing decisions. With this good corporate image, it helps people make decisions to transact in the company. Because they already believe in such a good reputation, of course, people do not buy just once, but many times. Thus the indicators included in the image of the maker include: popularity, credibility, company network, and the users themselves / users.

User image, is a set of associations that consumers perceive to users who use a product or service. User image is one indicator of a brand image and is often a reference for consumers in making purchasing decisions. In favorable conditions, the user of a product has a very strategic role in marketing communications. So, the image of the user will influence customer behavior in buying. Thus the indicators in the image of the user include: the user himself, as well as his social status.

Product image, is a set of associations that consumers perceive a product. Product image is seen as an important element in influencing consumer purchasing decisions. The better and the quality of a product, the higher the satisfaction that will be received by consumers. Thus the indicators in the product image include: attributes of the product, benefits for consumers, and guarantees (Simamora, 2011).

According to Kottler and Keller, brand image consists of the following components: Attributes is a descriptive definition of the features that exist in a product or service. 1) Product attributes are defined as the ingredients needed so that the product functions that consumers are looking for can work. In connection with the physical composition or requirements of a service offered, it can function. 2) Non product attributes, are external aspects of a 
product that are related to the purchase and consumption of a product or service. Consists of: information about the price, packaging and design of the product, the person, per group or celebrity who uses the product or service, how and where the product or service is used.

\section{Benefits the personal value} attributed by consumers to the attributes of the product or service. 1) Functional benefits: it relates to meeting basic needs such as physical needs and security or problem solving. 2) Experiental benefits : relates to the feelings that arise from using a product or service. This benefit satisfies experimental needs such as sensory satisfaction. 3) Symbolic benefits : relates to the need for social approval or one's personal expression and selfesteem. Consumers will appreciate the brand's values of prestige, exclusivity and fashion style because these things relate to their self-concept.

Brand Attitude defined as an overall evaluation of a brand, what consumers believe about certain brands to what extent consumers believe that the product or service has certain attributes or advantages, and evaluative assessment of that belief is how good or bad a certain product is. product if it has these attributes or advantages (Kotler dan Keller, 2017).

\section{The Role of School Citizens in Building} a Brand Image

According to Suhardono, the role according to social science means a function that is carried out by a person when occupying a position in a certain social structure (Soerjono Soekanto, 2013). By holding a certain position, a person can play their function because of the position they occupy. This means that it shows the active dynamic connotation of the role phenomenon. A person is said to play a role when he exercises the rights and obligations which are an inseparable part of the status he carries. Each social status is related to one or more social status.

The word citizen in the large Indonesian dictionary means participant, member of an organization, family or association. When combined with the word school, school residents can be interpreted as participants or members of the school organization. The position of school residents is also stated in Law Number 20 of 2003 concerning the national education system which consists of students, educators, school principals, and educational staff. From the description previously described, it can be concluded that the role of school members can be interpreted as the implementation of the rights and obligations of school principals, educators, educational staff, and students according to the social position they occupy. 
Keller stated that several factors that influence the formation of a brand image include: Product excellence is one of the factors forming a brand image, where the product is superior in competition. Because of the superiority of quality (model and comfort) and characteristics that cause a product to have its own appeal to consumers. Favorability of brand association is a brand association where consumers believe that the attributes and benefits provided by a brand will be able to meet or satisfy their needs and desires so that they form a positive attitude towards the brand.

Brand strength is a brand association depending on how information is entered into the memory of consumers and how the process survives as part of the brand image. The strength of this brand association is a function of the amount of information processing received in the coding process. When a consumer is actively deciphering the meaning of information about a product or service, a stronger association will be created in the consumer's memory. The importance of brand association to consumer memory depends on how a brand is considered.

The uniqueness of a brand is that the association towards a brand must inevitably be shared with other brands. Therefore, a competitive advantage must be created that can be used as an excuse for consumers to choose a particular brand. By positioning the brand more towards experience or selfbenefit from the product image. From the existing differences, both products, services, personnel, and channels are expected to make a difference from its competitors, which can provide benefits for producers and consumers (Kotler dan Keller, 2017).

The process of building a brand image for educational institutions can be described as follows: Forming perceptions, forming perceptions about educational institutions and everything in them are the first steps in building a brand image. This can be done by forming an image of the target segment about the identity of the school or educational institution. Maintaining perceptions, positive perceptions about educational institutions that have been formed and have become a strong brand image in the minds of the people need to be maintained, maintained, and even continuously developed. If the positive perceptions that have been embedded in the identity of educational institutions cannot be properly maintained, the image of educational institutions in the eyes of the community will decline and even be forgotten. Change the perception of educational institutions that are less profitable. Educational institutions are inseparable from deficiencies in the management process, where these 
deficiencies have an impact on the formation of $a$ positive brand image of the institution (RUKMANA, 2016).

Of the various theories that have been described previously about the role w arga school in the establishment of brand image, it can be concluded that the school community has the role of forming a brand image which must they carry out in their routines in educational institutions stipulated in the law on the rights and obligations of citizens of the school at educational institutions. In addition to these routines, there are three important things that are inherent in each school member regarding the formation of a brand image in educational institutions, namely how they form perceptions, maintain perceptions, and change perceptions of the brand image that exists in the identity of educational institutions.

\section{RESEARCH METHODS}

The type of research used in this research is qualitative research, because the research is carried out in natural conditions, the research object develops as it happens, is not manipulated and the presence of the researcher does not affect the dynamics of the object under study. This research is descriptive in nature, namely research that is intended to collect information about the status of an existing symptom, namely the state of the symptoms according to what they were at the time the research was conducted.

The research location is MA Al-Ikhlas Ujung Bone, which is located in Ujung Village, Bone Regency, South Sulawesi Province. The reason for choosing the research subjects was because the institution was an educational institution that had a very good reputation, especially in building a brand image. The data in this study are divided into primary data and secondary data. Sources of research data are residents of the MA Al-Ikhlas Ujung Bone school, which consists of the Principal of Madrasah and his staff, educators, education personnel, and students. The choice of data sources mentioned is because they all play an important role in the process of forming a brand image. Data collection methods consisted of observation, interviews, and documentation. Data analysis techniques, namely: data reduction, data display, and drawing conclusions (Creswell, 2012; Hamid, 2011; Lexy J, 2011).

\section{RESULTS AND DISCUSSION}

The results of the research on the role of school members in building brand image at MA Al-Ikhlas Ujung Bone, namely: 1) The characteristics of the MA Al-Ikhlas Ujung Bone brand image consist of the image of the maker, the image of the user, the image of the product. 2) $\mathrm{P}$ eran $\mathrm{w}$ arga school in building brand image in the MA Al-Ikhlas 
Edge Bone consists of shaping perceptions, maintain perceptions, changing perceptions. Based on the results of this study, the discussion of the research results can be described as follows:

Characteristics of Brand Image at MA Al-Ikhlas Ujung Bone Image Maker

The findings of the research show that the image of the maker at MA Al-Ikhlas Ujung Bone is: there is a national figure, namely Prof. Dr. KH. NazaruddinUmar who acts as an icon brand image. Secondly: consistency MA Al-Ikhlas Ujung Bone maintain the credibility of the management of the institution through the ISO 9001: 2015 . Third: Network-owned cooperative MA Al-Ikhlas Edge Bone national level and its International 1 , such as the MOU of cooperation in education with universities and abroad, cooperation in the form of easy access for alumni to continue their education at the university. Fourth: MA Al-Ikhlas Ujung Bone maintains the popularity of the institution by actively updating and disseminating MA Al-Ikhlas Ujung Bone activities to the community through the alikhlasbone.ac.id website, and the facebookpage https://www.facebook.com/ pg/alikhlasujung .

The findings obtained from the research results show that there are national figures who act as brand image icons at MA
Al-Ikhlas Ujung Bone in accordance with the theory expressed by Kotler and Keller that the important components of a brand image are in service managers, Simamora also revealed that popularity is a brand image indicator. Another finding is the existence of ISO 9001: 2015 certification owned by MA Al-Ikhlas Ujung Bone which aims to maintain the credibility of the educational institution in line with Simamora's theory that credibility is an indicator of brand image. It was also found that there was a collaborative network built by MA Al-Ikhlas Ujung Bone which was not only at the local level but up to the international level, this was also a brand image as expressed by Simamora that the indicator of brand image is the network that is owned.

From the above discussion, it can be concluded that MA Al-Ikhlas Ujung Bone meets all the brand image criteria for the image component maker. The indicators of fulfillment in question are the existence of a national figure as an institution icon that strengthens the brand image in terms of popularity and personal image, then the ISO 9001: 2015 certification becomes an indicator of fulfillment of credibility points, finally the local to international level cooperation owned by MA Al-Ikhlas Ujung Bone be the fulfillment of cooperation points. 


\section{User Image}

The results of research on the characteristics of the brand image of $\mathrm{MA} \mathrm{Al}$ Ikhlas Ujung Bone in terms of user image, namely: first: most students feel happy going to school because of the many friends from various regions, being independent, and getting very useful knowledge. Second: MA Al-Ikhlas Ujung Bone students feel proud to be part of an educational institution because of the many achievements students have made from regional to international levels. In addition, the ease with which alumni can continue their studies at wellknown universities at home and abroad is also the pride of students who attend these educational institutions.

The findings obtained from the research results show that students feel happy going to school because of the many friends from various regions, being independent, and getting very useful knowledge. This is in accordance with Simamora's theory that the indicator of brand image is a condition that benefits the user from using a service product. These findings are also in line with Kotler and Keller's theory which states that the brand image indicator is in the form of personal value gains attributed to consumers to product or service attributes which consist of meeting basic needs such as physical needs and security or problem solving, also related to feelings that are appears using a product or service.

Another finding is the feeling of pride by students being part of MA Al-Ikhlas Ujung Bone due to the many achievements students have obtained from regional to international levels, as well as the ease for alumni to continue their studies at wellknown universities at home and abroad, because of this. MA Al-Ikhlas Ujung Bone students have high self-confidence, or feel honored and have a better social status. This finding is in line with Kotler and Keller's theory which says that one component of brand image is profit, which is related to the need for social approval or personal expression and one's selfesteem, consumers will appreciate the values of prestige and exclusivity because these things are related to their self-concept.

From the above discussion it can be concluded that MA Al-Ikhlas Ujung Bone meets all the brand image criteria for the user image component. The fulfillment indicator is in the form of feeling happy and proud for MA Al-Ikhlas Ujung Bone students who have become part of the institution. Feelings of pleasure and pride give birth to a sense of self-confidence, feeling honored and having a better social status that meets the criteria for the component en rand image in the form of 
the need for social approval or one's personal expression and self-esteem.

\section{Product Image}

The results of research on the characteristics of the brand image of MA Al-Ikhlas Ujung Bone in terms of product image, namely the benefits offered and / or given to students in the form of an education and learning system in the form of an Islamic Boarding School, additional benefits that can be obtained by MA AlIkhlas Ujung Bone students. in the form of extracurricular activities, and quality assurance, in this case an accreditation certificate from the National Accreditation Board BAN-S / M with a score of 89 rank A (very good).

The findings obtained from the results of the research show that various benefits that can be obtained by students such as an education system in the form of a boarding school, extracurricular activities and quality assurance of $\mathrm{A}$ accreditation from the National Accreditation Board BAN-S / M are components of brand image. This is in line with Simamora's theory that product image is seen as an important element in influencing consumer purchasing decisions. The better and the quality of a product, the higher the satisfaction that will be received by consumers. These findings are also in line with Kotler and Keller's theory which explains that the component of brand image is an overall evaluation of a brand, the extent to which consumers believe that the product or service has certain attributes or advantages, and evaluative judgments of how good or bad a product is if have these attributes or advantages.

From the above discussion it can be concluded that MA Al-Ikhlas Ujung Bone meets all the brand image criteria for the product image component. The indicators of fulfillment are the existence of an education system in the form of boarding schools, extracurricular activities and quality assurance of $\mathrm{A}$ accreditation from the National Accreditation Board of BAN-S /M.

The Role of School Citizens in Building a Brand Image at MA Al-Ikhlas Ujung Bone Forming Perception

The results of research on the role of school residents in building brand image at MA Al-Ikhlas Ujung Bone, especially in shaping perceptions in the form of building positive perceptions, building cooperation, conducting comparative studies, maintaining institutional secrets, making innovations, seeking development information, spreading positive information, carry out activities according to competence, participate in every community activity, and do not do things that are detrimental to madrasah.

Everything is a way of forming or building perceptions in terms of forming an 
image of an institution in accordance with

Yulia Rukmana's theory of perception formation where the process of forming perceptions in building a brand image is the formation of positive perceptions of school images.

\section{Maintaining Perception}

The results of research on the role of school members in building brand image at MA Al-Ikhlas Ujung Bone in terms of maintaining and maintaining positive perceptions, namely through fostering a sense of belonging to the institution, instilling an attitude of sincerity and responsibility, giving the best to the institution, being an example. which is good for society; love school; spread positive things to families and society; maintain the good name and pride of the school.

Based on the research findings above, the role of school members in building brand image at MA Al-Ikhlas Ujung Bone is in the form of fostering a sense of belonging to the institution; instill an attitude of sincerity and responsibility; provide the best for the institution; be a good example for society; love school; spread positive things to families and society; maintaining the good name and pride of the school, fulfilling Yulia Rukmana's theory indicators in building brand image in educational institutions.

\section{Changing Perceptions}

The results of research regarding the role of school members in building brand image at MA Al-Ikhlas Ujung Bone, especially in changing perceptions, namely conducting continuous evaluations; listen to public input; prevent violence in the school environment; show good character; disclosure of institutional information; and displays student achievements. This is consistent with the theory Yulia Rukmana that the institution needs to realize its shortcomings and apply various methods for converting $\mathrm{p}$ ersepsi negative, thus the brand image of the negative will turn out to be positive.

\section{CONCLUSION}

The conclusions of this study are as follows: 1) Characteristics of the brand image in the MA Al-Ikhlas Edge Bone is as follows: the national character that acts as an icon brand image, $m$ enjaga credibility of the management of the institution through the certification of IS O 9001: 2015, a network of cooperation level nationally and internationally, keep popularity institutions in $\mathrm{m}$ community, make students feel happy in school and feel proud to be part of the school, make it easy for alumni to continue their studies at well-known universities at home and abroad, the education and learning system in the form of an Islamic Boarding school, activate extracurricular 
activities, improve quality assurance in terms of This is an accreditation from the National Accreditation Board BAN-S / M.

2) The role of school members in building a brand image at MA Al-Ikhlas Ujung Bone, namely: building cooperation, conducting comparative studies, maintaining institutional secrets, conducting innovation, seeking development information, disseminating positive information, carrying out activities according to competence, participating in every community activity, and not doing things that are detrimental to the madrasah, creating a sense of belonging to the institution; instilling sincerity and responsibility, giving the best for the institution; be a good example for society; love school, spread positive things to family and society, maintain the good name and pride of the school, conduct continuous evaluation, listen to community input; preventing violence in the school area, showing good character, disclosing institutional information, and displaying student achievements.

\section{REFERENCES}

Ahmad, K. B. (2015). Educational practice: Lessons to be learned from madrasah and religious schools in contemporary Southeast Asia. Indonesian Journal of Islam and Muslim Societies, 5(1), 29-48.

Akhyadi, A. S., \& Mulyono, D. (2019). Program Parenting Dalam Meningkatkan Kualitas Pendidikan
Keluarga. Abdimas Siliwangi, 1(1), 18. https://doi.org/10.22460/as.v1i1p1 $-8.34$

Alfiyanto, A. (2020). MANAJEMEN PEMASARAN JASA PENDIDIKAN BERBASIS BUDAYA RELIGIUS. Adaara: Jurnal Manajemen Pendidikan Islam, 10(1), 53-62. https://doi.org/10.35673/ajmpi.v10 i1.867

Alwi, S., Che-Ha, N., Nguyen, B., Ghazali, E. M., Mutum, D. M., \& Kitchen, P. J. (2019). Projecting university brand image via satisfaction and behavioral response: Perspectives from UKbased Malaysian students. Qualitative Market Research: An International Journal, 23(1), 47-68. https://doi.org/10.1108/QMR-122017-0191

Alwi, S. F. S., \& Kitchen, P. J. (2014). Projecting corporate brand image and behavioral response in business schools: Cognitive or affective brand attributes? Journal of Business Research, 67(11), 2324-2336.

Andi, M. S. (2009). Brand Belief: Strategi Membangun Merek Berbasis Keyakinan. In Salemba Empat. https://doi.org/10.1109/IEEESTD .2014 .6853300

Asyari, H., Munawwaroh, Z., Kurniatun, T. C., \& Aedi, N. (2018). Strategy for Application of Risk Management on the Implementation of Renstra. TARBIYA: Journal of Education in Muslim Society, 5(1), 57-65. https://doi.org/10.15408/tjems.v5i 1.9528

Chen, C.-F., \& Chen, C.-T. (2014). The Effect of Higher Education Brand 
Images on Satisfaction and Lifetime Value from Students' Viewpoint. The Anthropologist, 17(1), 137-145. https://doi.org/10.1080/09720073. 2014.11891423

Creswell, J. W. (2012). Educational research: Planning, conducting, and evaluating quantitative and qualitative research (4th ed). Pearson.

de Chernatony, L., \& McDonald, M. (2012). Creating powerful brands: In consumer, service and industrial markets. In Creating Powerful Brands: In Consumer, Service and Industrial Markets.

https://doi.org/10.4324/978008047 6919

DWIYAMA, F. (2019). BRAND IMAGE: UPAYA

MEMASARKAN PENDIDIKAN BAGI LEMBAGA YANG KURANG MAMPU BERSAING. Adaara: Jurnal Manajemen Pendidikan Islam. https://doi.org/10.35673/ajmpi.v9i 2.424

Hamid, D. (2011). Metode penelitian Pendidikan (Ed. 2). Alfabeta.

Ibrahim, G., \& Hamidah, H. (2017). THE EFFECT OF IMAGE, PROMOTION, COMMUNICATION, AND FACILITIES ON SENIOR HIGHT SCHOOL STUDENT'S INTEREST. IJER - INDONESIAN JOURNAL OF EDUCATIONAL REVIEW.

https://doi.org/10.21009/ijer.04.02. 07

Ismail, F. (2018). MANAJEMEN BERBASIS SEKOLAH: SOLUSI PENINGKATAN KCALITAS PENDIDIKAN. Jurnal Pendidikan Islam Iqra'. https://doi.org/10.30984/jpii.v2i2.5 41

Kartajaya, H. (2006). HERMAWAN KARTAJAYA ON SELLING SERI 9 ELEMEN MARKETING. Bandung: Miran.

Kotler. (2013). Manajemen Pemasaran Jilid 2. In Penerbit Erlangga.

Kotler dan Keller. (2017). Manajemen Pemasaran, Edisi 12, Jilid 1, PT.Indeks,. Jakarta. In E - Jurnal Riset Manajemen.

Kotler, P., \& Keller, K. L. (2009). Marketing management (13th ed.). In Prentice Hall.

Kotler, Philip. (2011). Manajemen Pemasaran (terjemahan). In Edisi Millenium, Jilid 1.

Kotler, Philip, \& Keller, K. L. (2009). Manajemen pemasaran Jilid 1. In Jakarta.

Lexy J, M. (2011). Metodologi penelitian Kualitatif (29th ed.). Rosdakarya.

Muhammadi, N., Marzuki, S. C. bin H., \& Hussin, M. Y. bin M. (2015). The Madrasah Leadership, Teacher Performance and Learning Culture to Improve Quality at Madrasah Tsanawiyah Negeri Jakarta of South. Journal of Management and Sustainability, 129. https://heinonline.org/HOL/Page? handle $=$ hein.journals $/$ jms $5 \&$ \&id $=342$ \&div $=$ \&collection $=$

Plumeyer, A., Kottemann, P., Böger, D., \& Decker, R. (2019). Measuring brand image: A systematic review, practical guidance, and future research directions. Review of Managerial Science, 13(2), 227-265. https://doi.org/10.1007/s11846017-0251-2 
Plungpongpan, J., Tiangsoongnern, L., \& Speece, M. (2016). University social responsibility and brand image of private universities in Bangkok. The International Journal of Educational Management, 30(4), 571-591. https://doi.org/10.1108/IJEM-102014-0136

R, A. H. A., \& Ummah, B. (2019). Strategi Image Branding Universitas Nurul Jadid di Era Revolusi Industri 4.0. TARBIYATUNA, 12(1), 59-81. https://doi.org/10.36835/tarbiyatu na.v12i1.352

Roziqin, Z., \& Rozaq, H. (2018). MENGGAGAS COMPETITIVE ADVANTAGE MELALUI BRANDING IMAGE DI MADRASAH ALIYAH NURUL JADID PAITON PROBOLINGGO. Jurnal Ilmiah Didaktika. https://doi.org/10.22373/jid.v18i2. 3244

RUKMANA, Y. (2016). STARTEGI MEMBANGUN BRAND IMAGE $D A L A M \quad M E N I N G K A T K A N$ $D A Y A \quad S A I N G \quad L E M B A G A$ PENDIDIKAN. UIN Maulana Malik Ibrahim Malang.

Schwab, K. (2016). The global competitiveness report 2016-2017: Insight report. World Economic Forum.

Sharma, A. A., Rao, V. R., \& Popli, S. (2013). Measuring consumer-based brand equity for Indian business schools. Journal of Marketing for Higher Education, 23(2), 175-203. https://doi.org/10.1080/08841241. 2013.866609

Simamora. (2011). Riset Pemasaran. Gramedia Pustaka Utama.
Soerjono Soekanto. (2013). Sosiologi Suatu Pengantar. PT. RajaGrafindo Persada. Suwadi, S. (2017). Educational Leadership Based on Social Capital for Improving Quality of Private Secondary School. Jurnal Pendidikan Islam, 6(2), 449. https://doi.org/10.14421/jpi.2017.6 2.449-478

Wibowo, A. E. (2018). Strategi membangun brand image dalam meningkatakan daya saing lembaga pendidikan man 2 ponorogo. Tesis. 